1 Gedde-Dahl TW, Bjark P, Høiby EA, Høst JH, Brunn JN. Severity of meningococcal disease: assessment by factors and scores and implications for patient management. Rev Infect Dis 1990; 12:973-91.

2 Ferguson JH, Chapman OD. Fulminating meningococcic infections and the so-called Waterhouse-Friderichsen syndrome. Am f Pathol 1947; 24: 76395 .

3 Margaretten W, McAdams AJ. An appraisal of fulminant meningococcemia with reference to the Shwartzmann phenomenon. Am F Med 1958;25:868-76.

4 Colman RW, Robboy SJ, Minna JD. Disseminated intravascular coagulation (DIC): an approach. Am $\mathcal{F}$ Med 1972; 52: 679-89.

5 Evans RW, Glick B, Kimball F, Lobell $M$. Fatal intravascular consumption coagulopathy in meningococcal sepsis. Am $\mathcal{F}$ Med 1969; 46: $910-8$.

6 McGehee WG, Rapaport SI, Hjort PF. Intravascular coagulation in fulminant meningococcemia. Ann Intern Med 1967; 67: 250-60.

7 Gimbrone MA. Vascular endothelium: nature's blood container. In: Gimbrone MA, ed. Endothelium in hemostasis and thrombosis. Edinburgh: Churchill Livingstone, 1986: 1-12.

8 Bone RC. Modulators of coagulation: a critical appraisal of their role in sepsis. Arch Intern Med 1992; 152: 1381-9.

9 Renesto P, Kadiri C, Chignard M. Combined activation of platelets by cathepsin $\mathrm{G}$ and platelet activating factor, two neutrophil-derived agonists. cathepsin G and platelet activati

10 Brandtzaeg P, Joø G, Brusletto B, Kierulf P. Plasminogen activator inhibitor 1 and 2, alpha-2-antiplasmin, plasminogen, and endotoxin levels in systemic meningococcal disease. Thromb Res 1990; 57:271-8.

11 Lüscher EF. Activated leukocytes and the hemostatic system. Rev Infect Dis 1987; 9 (suppl 5): S546-52.

12 Fourrier F, Lestavel P, Chopin C, et al. Meningococcemia and purpura fulminans in adults: acute deficiencies of proteins $C$ and $S$ and early treatment with antithrombin III concentrates. Intensive Care Medicine 1990; 16: 121-4.

13 Heyderman RS, Klein NJ, Shennan GI, Levin M. Deficiency of prostacyclin production in meningococcal shock. Arch Dis Child 1991; 66: 1296-9.

14 Heyderman RS, Klein NJ, Shennan GI, Levin M. Modulation of the anticoagulant properties of glycosaminoglycans on the surface of the vascular endothelium by endotoxin and neutrophils: evaluation by an amidolytic assay. Thromb Res 1992; 67: 677-85.

15 van der Poll T, Büller HR, ten Cate H, et al. Activation of coagulation after administration of tumor necrosis factor to normal subjects. $N$ Engl $\mathcal{f}$ Med 1990; 322: 1621-7.

\section{Aetiology of Crohn's disease}

Crohn's disease is an idiopathic inflammation of the gastrointestinal tract occurring anywhere from the mouth to anus, although it is predominantly ileocaecal. It is characteristically patchy, transmural, contains non-caseating granulomas, and has a chronic clinical course with recurrent relapses. It is not seen in infants but can develop in children as young as 4 years of age. Thereafter the incidence increases reaching a peak in late adolescence. It is difficult to determine the exact prevalence of Crohn's disease in the UK but it may be around 50 per 100000 of the population and 10 per 100000 children. $^{1}$ Thus Crohn's disease is a significant paediatric problem. Moreover as active disease is associated with diarrhoea, malabsorption, and a general malaise, children with Crohn's disease may be undernourished and a significant proportion are growth impaired. To determine the cause of Crohn's disease is the most significant challenge in gastroenterology today and has been the subject of intense interest over the last 20 years.

Basically, there are three main theories for the cause of Crohn's disease. Firstly, there are those who consider that Crohn's disease is due to an infection, so that it is possible to 'catch' Crohn's disease from an environmental agent; it is however worth pointing out that the epidemiology of Crohn's disease shows no evidence of transmissability. Secondly, there are those who consider that Crohn's disease is due to an immunological hypersensitivity response to antigens (as yet unidentified) in the gut wall. These are most likely to be antigens and components of the normal flora. Thirdly, there are those who consider Crohn's disease to be vasculitis of the submucosal vessels and that mucosal ulceration is a secondary event due to ischaemia. Evidence for these three points of view will be considered. There are also a number of other theories, such as food hypersensitivity or that Crohn's is caused by baker's yeast, but as the evidence for these is scant, they will not be considered here.
16 Girardin E, Grau GE, Dayer J-M, et al. Tumour necrosis factor and interleukin-1 in the serum of children with severe infectious purpura. $N$ Engl f Med 1988; 319: 397-400.

17 Wachtfogel YT, Abrams W, Kuccich U, Weinbaum G, Schapira M, Colman RW. Fibronectin degradation products containing the cytoadhesive tetrapeptide stimulate human neutrophil degranulation. $\mathcal{f}$ Clin Invest 1988; 81: $1310-6$.

18 Jafari HS, McCracken GH. Sepsis and septic shock: a review for clinicians. Pediatr Infect Dis $\mathcal{F}$ 1992; 11 : 739-49.

19 Glynn MFX, Silver E, Redmond MD. A randomised trial of cryoprecipitate replacement of fibronectin deficiencies in the critically ill. Am Rev Respir Dis 1984; 129: A102.

20 Lundsgaard-Hansen P, Doran JE, Rubli E, et al. Purified fibronectin administration to patients with severe abdominal infections: a controlled trial. Ann Surg 1985; 202: 745-9.

21 Braude AI, Douglas H, Davis CE. Treatment and prevention of intravascular coagulation with antiserum to endotoxin. F Infect Dis 1973; 128: S157-64.

22 Corrigan JJ, Ray WL, May N. Changes in the blood coagulation system associated with septicemia. NEngl F Med 1968; 279: 851-6.

23 Gérard P, Moriau M, Bachy A, Malvaux P, De Meyer R. Meningococcal purpura: report of 19 patients treated with heparin. $\mathcal{F}$ Pediatr 1973; 82: $780-6$

24 Zhang CW, Xie WM, Li YF, He ML, Wang ND, Yue JS. Estimation of free heparin in blood and observation of the therapeutic effect of protamine in epidemic hemorrhagic fever. Chung Hua Nei Ko Tsa Chih 1981; 20: 711-5.

25 Klein N, Shennan G, Heyderman R, Levin M. Alteration in glycosaminoglycan metabolism and .urface charge on human umbilical vein endothelia cells induced by cytokines, endotoxin and neutrophils. F Cell Sci 1992; 102 821-32.

26 Ditter H, Matthias FR, Voss R, Lohmann E. Beneficial effects of prostacyclin in a rabbit endotoxin shock model. Thromb Res 1988; 51: 403-15.

27 Nava E, Palmer RMJ, Moncada S. Inhibition of nitric oxide synthesis in septic shock: how much is beneficial? Lancet 1991; 338: 1555-7.

28 Taylor FJ, Chang A, Ruf W, et al. Lethal E coli septic shock is prevented by blocking tissue factor with monoclonal antibody. Circ Shock 1991; 33: 12734.

29 Angelini GD, Cooper GJ, Lamarra M, Bryan AJ. Unorthodox use of aprotinin to control life-threatening bleeding after cardiopulmonary bypass. Lancet 1990; 335: 799-800.

\section{Crohn's disease is due to a transmissable environmental agent}

Although various viruses have been reported to be important in Crohn's disease, most work has concentrated on the role of mycobacterial infection. The original description of the disease by Crohn himself focused on the differences between Crohn's disease and intestinal tuberculosis. ${ }^{2}$ Histopathologically there are similarities between the two diseases, but the complete absence of acid fast bacilli in Crohn's disease and the fact that the granulomas in Crohn's disease are noncaseating has generally dampened enthusiasm for this notion. Nevertheless interest in mycobacterial origin of Crohn's disease was rekindled in 1984 by the isolation of an organism, later identified as a slow growing Mycobacterium paratuberculosis from two North American children with Crohn's disease. $^{3}$ This bacterium exists as a cell wall deficient variant in vivo which regains its cell wall after in vitro culture. This organism is of special interest as $M$ paratuberculosis is the causative agent of Johne's disease, a chronic enteritis of cattle. Inoculation of massive amounts of this organism to a goat caused terminal ileitis with non-caseating granulomas, and acid fast bacilli were extremely difficult to detect in the tissues. This however is unlike Johne's disease in cattle in which the mucosa is filled with acid fast bacilli.

In more detailed studies, conventional mycobacteria were isolated from one third of the biopsy specimens of Crohn's disease, $25 \%$ of ulcerative colitis biopsies, and $40 \%$ from controls without inflammatory bowel disease. ${ }^{4}$ These were most commonly of the Mycobacterium avium complex. Only one isolate from a patient with ulcerative colitis was similar to the $M$ paratuberculosis isolated from the children previously. Thus with rigorous culture techniques, mycobacteria can be isolated from the intestinal mucosa of healthy patients and those with inflammatory bowel disease. Cell wall deficient organisms were isolated from a number of patients with 
Crohn's disease, a few ulcerative colitis patients, but not from the control tissue. No quantitative bacteriology has been carried out, but presumably these mycobacteria are present in very low numbers and are environmental contaminants.

This however has not deterred some investigators from continuing to pursue the idea that infection with $M$ paratuberculosis is the cause of Crohn's disease, despite the fact that serologically there is no evidence for this infection, and that by immunohistochemistry, mycobacteria cannot be detected in the gut wall in Crohn's disease. ${ }^{6}$ Using a cDNA probe specific for $M$ paratuberculosis, no mycobacterial DNA can be detected in Crohn's bowel by Southern blotting. Using the more sensitive polymerase chain reaction (PCR) to detect $M$ paratuberculosis DNA, positive signals were reported from $65 \%$ of Crohn's patients, $4 \cdot 3 \%$ of patients with ulcerative colitis, and $12.5 \%$ of controls. ${ }^{8}$ With this technique it is difficult to determine how many bacteria are present in the tissues, but it would be of the order of only several hundred per gram of tissue. From an immunological point of view it is difficult so see how so few organisms could elicit such a strong inflammatory response, especially if, in vivo, the $M$ paratuberculosis lacks a cell wall, as the cell wall is the major stimulus for the immune response in mycobacterial infections. These studies were carried out with full thickness resected material from patients with long standing disease and it would be of great interest to determine if the same results would be obtained from mucosal biopsy specimens of children with new disease.

Finally, it is clear that $M$ paratuberculosis is ubiquitous in the environment as it was found in a proportion of healthy individuals. Thus the presence of this organism in the gut is clearly not associated with disease.

\section{Crohn's disease is an immunological hypersensitivity disease}

This theory is not incompatible with a distinct infectious aetiological agent as the local immune reaction has to be driven by antigen(s), which might be that agent. There is no doubt, however, that the tissue damage and mucosal ulceration in Crohn's disease are due to immunological hypersensitivity. The earliest signs of Crohn's disease are focal accumulations of mononuclear cells ( $T$ cells and macrophages) in the lamina propria and apthous ulceration of the intestinal lymphoid follicles. More diseased mucosa contain large numbers of phenotypically activated $T$ cells and macrophages, ${ }^{9}$ there are large numbers of IgG plasma cells, ${ }^{10}$ extensive local complement activation, ${ }^{11}$ and an abundance of non-specific effector cells such as mast cells, eosinophils, and neutrophils. Standard treatment is with immunosuppressives such as prednisolone and azathioprine, and more recently with cyclosporin. ${ }^{12}$ The crucial question however is the antigenic stimulus for this inflammatory response and which aspect of the immune response is responsible for the primary lesion.

It has always seemed clear to the author that many of the features of Crohn's disease, such as granulomas, macrophage infiltrate, and fibrosis are also those seen in chronic cell mediated immune reactions. Thus it was little surprise that an ongoing cell mediated immune response has recently been identified functionally in the mucosa of Crohn's disease, but not ulcerative colitis, by both quantitative PCR $^{13}$ and functional lymphokine analysis. ${ }^{14}$ The observation that activated $T$ cells are not seen in the mucosa in ulcerative colitis shows that $\mathrm{T}$ cell activation in Crohn's disease is not a non-specific secondary effect due to increased antigen uptake across a damaged epithelium, but may be a primary event. However until the specificity of these $T$ cells is identified, the stimulus for the local $T$ cell hypersensitivity will remain unknown. Cell mediated immunity in the mucosa and lymphokine production (for example interferon gamma) can cause mucosal ulceration and increase epithelial permeability. ${ }^{15}$ Subsequent secondary ingress of lumenal contents may then elicit a vigorous phlogistic IgG response that perpetuates and increases tissue damage. The IgG response is markedly higher adjacent to ulcers than in the areas between the lesions. ${ }^{10}$

Although it is still contentious, the stimulus for the inflammation is likely to be from the faecal stream. After resection of diseased bowel, there is no disease in the neoterminal ileum if the segment is bypassed. ${ }^{16}$ After reconnection to the faecal stream, apthous ulceration and inflammation develop.

\section{INTESTINAL PERMEABILITY}

The predisposing factors to develop Crohn's disease are still not known and the genetic link is not strong. There was some excitement with the demonstration that relatives of Crohn's patients appeared to have increased intestinal permeability, thereby providing a mechanism whereby immunological sensitisation to the flora could occur. ${ }^{17}$ Unfortunately, this observation has not been repeated. ${ }^{18}$

\section{ELEMENTAL DIET}

Proponents of an immunological origin for Crohn's disease have some difficulty explaining the proved efficacy of elemental or polymeric liquid diets in inducing remission of Crohn's disease, ${ }^{1920}$ especially as there is little evidence for sensitivity to foods in Crohn's disease. Many patients with active Crohn's disease are undernourished but it is puzzling that improved nutrition can be as effective as immunosuppressive treatment in healing the intestine. Improved nutrition may allow the development of a previously suppressed immunological feedback loop, so that the host's own endogenous immunomodulators can suppress the active inflammation. Alternatively, elemental diet may quantitatively or qualitatively alter the gut flora, removing or reducing the stimulus for inflammation from the faecal stream. It should also be remembered that the faecal flora in Crohn's disease is different from normal, with higher numbers of anaerobic cocci. ${ }^{21}$

\section{Crohn's disease is a vasculitis caused by multifocal gastrointestinal infarction}

It has been recognised for many years that there are vascular changes in the submucosa in active Crohn's disease, although it was assumed that these were secondary to the transmural inflammation originating in the mucosa. Extremely detailed studies on vasculature in Crohn's disease by Wakefield and colleagues however suggested that vascular injury and focal arteritis were early events, even occurring in the submucosa underlying normal mucosa. ${ }^{22}$ Arterial occlusion follows the arteritis and there is multiple gastrointestinal infarction, so that the mucosal changes are due to ischaemia. In further studies it was shown that many of the granulomas in Crohn's disease were associated with vessels, ${ }^{23}$ further implicating the intestinal microvasculature in the pathogenesis.

The key to this notion is the definition of the earliest lesion. Traditionally it has been considered that discrete punctate apthous ulceration of the mucosa overlying lymphoid follicles, visible endoscopically, is the earliest sign of Crohn's disease. However any underlying vascular changes would not be seen endoscopically. In resected specimens, although vascular abnormalities may be visible below normal mucosa, the mucosa may have been previously diseased, but healed. In addition, even the association of granulomas with blood vessels does not prove that the granulomas arose in the vessel 
as tumour necrosis factor- $\alpha$, produced by cells in the granuloma,${ }^{24}$ is angiogenic. ${ }^{25}$ Finally, granulomatous vasculitis does not spontaneously develop, but is more likely a consequence of delayed hypersensitivity reactions. ${ }^{22}$ Again, there must be a stimulus to initiate the inflammation.

\section{Conclusions}

Research on Crohn's disease has progressed on two fronts. If a specific aetiological agent could be identified, then avoidance or prophylactic steps could be taken. If however there is no single aetiological agent, but the disease is a host intestinal hypersensitivity response to different stimuli in different individuals, then focus should take place on ways of specifically subverting the immune response. This latter point is urgently needed as although steroids, the mainstay of treatment, are effective at inducing clinical remission, endoscopic examination of the mucosa in patients in remission frequently continues to show mucosal damage. ${ }^{26}$ Thus even in remission there is ongoing subclinical, low grade mucosal inflammation which undoubtedly contributes to the mucosal ulceration, scarring, fibrosis, and strictures that are so characteristic of the disease.

It would be foolish to predict that no discrete aetiological agent will be found. However, it is now clear that terminal ileitis indistinguishable from Crohn's disease can be seen in children with neutrophil deficiency syndromes, such as glycogen storage disease or chronic granulomatous disease. ${ }^{27}{ }^{28}$ This tells us that antigens and bacteria from the gut are continually entering the mucosa, a process called translocation, but that they are degraded and destroyed by neutrophils. If this system is defective, there is antigen persistance and a terminal ileitis develops, presumably due to local immune reactions. Although there is little evidence for a primary neutrophil defect in Crohn's disease, persistent lumenal antigen penetration into the mucosa and sensitisation would explain the immunological features of the disease, without invoking a specific aetiological agent.

THOMAS T MACDONALD

Department of Paediatric Gastroenterology,

St Bartholomews Hospital

London ECIA 7BE

1 Walker-Smith JA. Inflammatory bowel disease in childhood. International Seminars in Paediatric Gastroenterology and Nutrition 1922; 1: 1-3.

2 Crohn BB, Ginzburg L, Oppenheimer G. Regional enteritis - a pathological and clinical entity. $\mathcal{F A M A}$ 1932; 99: 1323-9.
3 Chiodini RJ, Van Kruiningen HJ, Thayer WR. Possible role of mycobacteria in inflammatory bowel disease. Dig Dis Sci 1984; 29: 1073-85.

4 Graham DY, Markesich DC, Yoshimura H. Mycobacteria and inflammatory bowel disease. Results of culture. Gastroenterology 1987; 92: 436-42.

5 Tanaka K, Wilks M, Coates PJ, Farthing MJG, Walker-Smith JA, Tabacquali S. Mycobacterium paratuberculosis and Crohn's disease. Gut 1991; 32: 43-5.

6 Kobayashi K, Blaser M, Brown WR. Immunohistochemical examination for mycobacteria in intestinal tissues from patients with Crohn's disease. mycobacteria in intestinal tissues

7 Butcher PD, McFadden JJ; Hermon-Taylor J. Investigation of mycobacteria in Crohn's disease tissue by Southern blotting and DNA hybridisation with cloned mycobacterial genomic DNA probes from a Crohn's disease isolated mycobacteria. Gut 1988; 29: 1222-8.

8 Sanderson JD, Moss MT, Tizard MLV, Hermon-Taylor J. Mycobacterium paratuberculosis DNA in Crohn's disease tissue. Gut 1992; 33: 890-6.

9 Choy M-Y, Richman PI, Walker-Smith JA, MacDonald TT. Differential expression of CD25 (interleukin-2 receptor) on lamina propria $T$ cells and macrophages in the intestinal lesions in Crohn's disease and ulcerative colitis. Gut 1991; 31: 1365-70.

10 Brandtzaeg P. The B cell system. In: Brostoff J, Challacombe SB, eds. Food allergy and intolerance. London: Baillière Tindall, 1987: 118-55.

11 Halstensen TS, Mollnes TE, Brandtzaeg P. Persistent complement activation in submucosal blood vessels of active inflammatory bowel disease: immunohistochemical evidence. Gastroenterology 1989; 97: 10-9.

12 Brynskov J, Freund L, Rasmussen SN, et al. A placebo-controlled, doubleblind, randomised trial of cyclosporine therapy in active chronic Crohn's disease. N Engl F Med 1989; 321: 845-50.

13 Mullin GE, Lazenby AJ, Harris ML, Bayless TM, James SP. Increased interleukin-2 mRNA in the intestinal mucosal lesions of Crohn's disease but not ulcerative colitis. Gastroenterology 1992; 102: 1620-6.

14 Breese EM, Braegger CP, Corrigan CP, Walker-Smith JA, MacDonald TT. Lymphokine secreting cells in the intestinal mucosa in inflammatory bowel disease. Immunology (in press).

15 Madara JL, Stafford J. Intérferon- $\gamma$ directly affects barrier function of cultured intestinal epithelial monolayers. 7 Clin Invest 1989; 83: 724-7.

16 Rutgeerts $P$, Goboes $\mathrm{K}$, Peeters $M$, et al. Effect of faecal stream diversion on recurrence of Crohn's disease in the neoterminal ileum. Lancet 1991; 338: $771-4$

17 Hollander D, Vadheim CM, Brettholz E, et al. Increased intestinal permeability in patients with Crohn's disease and their relatives. Ann Intern Med 1986; 105: 883-5.

18 Teahon K, Smethurst P, Levi AJ, Menzies IS, Bjarnson I. Intestinal permeability in patients with Crohn's disease and their first degree relatives. Gut 1992; 33: 320-3.

19 Kirchner BS, Klich JR, Kalman SR, DeFavaro MV, Rosenberg I. Reversal of growth retardation in Crohn's disease with therapy emphasising oral growth retardation in Crohn's disease with therapy
nutritional restitution. Gastroenterology 1981; 80: 10-5.

20 Rigaud D, Cosnes J, Le Quintrec Y, et al. Controlled trial comparing two types of enteral nutrition in treatment of active Crohn's disease: elemental $v$ of enteral nutrition in treatment of

21 Van de Merwe JP. The human faecal flora and Crohn's disease. Antonie Van Leeuwenhoek 1984; 50: 691-700.

22 Wakefield AJ, Sawyerr AM, Dhillon AP, et al. Pathogenesis of Crohn's disease: multifocal gastrointestinal infarction. Lancet 1989; 334: 1057-62.

23 Wakefield AJ, Sankey EA, Dhillon AP, et al. Granulomatous vasculitis in Crohn's disease. Gastroenterology 1991; 100: 1279-87.

24 Kindler V, Sappino AP, Grau GE, Piguet PF, Vassalli P. The inducing role of tumor necrosis factor in the development of bactericidal granulomas during BCG infection. Cell 1989; 56: 731-40.

25 Frater-Schroder M, Risau W, Hallman R, Gautschi P, Bohlen P. Tumor necrosis factor type $\alpha$, a potent inhibitor of endothelial cell growth in vitro, is necrosis factor type $\alpha$, a potent inhibitor of endothelial cell growth

26 Modigliani R, Mary J-Y, Simon J-F, et al. Clinical, biological, and endoscopic picture of attacks of Crohn's disease. Evolution on prednisolone. Gastroenterology 1990; 98: 811-8.

27 Roe TF, Coates TD, Thomas DW, Miller JH, Gilsanz V. Treatment of chronic inflammatory bowel disease in glycogen storage disease type $1 \mathrm{~b}$ with colonystimulating factors. N Engl f Med 1992; 326: 1666-9.

28 Ament ME, Ochs HD. Gastrointestinal manifestations of chronic granulomatous disease. $N$ Engl F Med 1973; 288: 382-7. 